\title{
Differential Effects of Insulin Deficiency on Albumin and Fibrinogen Synthesis in Humans
}

\author{
Pierpaolo De Feo,` Margaret Gan Gaisano,` and Morey W. Haymond \\ ${ }^{*}$ Endocrine Research Unit, Mayo Clinic, Rochester, Minnesota 55905; ${ }^{\ddagger}$ Istituto di Patologia Medica, \\ University of Perugia, Italy; and \$Nemours Children's Clinic, Jacksonville, Florida 32247
}

\begin{abstract}
Insulin deficiency decreases tissue protein synthesis, albumin mRNA concentration, and albumin synthesis in rats. In contrast, insulin deficiency does not change, or, paradoxically, increases estimates of whole body protein synthesis in humans. To determine if such estimates of whole body protein synthesis could obscure potential differential effects of insulin on the synthetic rates of individual proteins, we determined whole body protein synthesis and albumin and fibrinogen fractional synthetic rates using 5-h simultaneous infusions of $\left[{ }^{14} \mathrm{C}\right.$ leucine and $\left[{ }^{13} \mathrm{C}\right]$ bicarbonate, in six type 1 diabetics during a continuous $i . v$. insulin infusion (to maintain euglycemia) and after short-term insulin withdrawal $(12 \pm 2 \mathrm{~h})$.

Insulin withdrawal increased $(P<0.03)$ whole body proteolysis by $\approx 35 \%$ and leucine oxidation by $\sim 100 \%$, but did not change ${ }^{13} \mathrm{CO}_{2}$ recovery from $\mathrm{NaH}^{13} \mathrm{CO}_{3}$ or estimates of whole body protein synthesis $(P=0.21)$. Insulin deficiency was associated with a $29 \%$ decrease $(P<0.03)$ in the albumin fractional synthetic rate but a $50 \%$ increase $(P<0.03)$ in that of fibrinogen.

These data provide strong evidence that albumin synthesis in humans is an insulin-sensitive process, a conclusion consistent with observations in rats. The increase in fibrinogen synthesis during insulin deficiency most likely reflects an acute phase protein response due to metabolic stress. These data suggest that the absence of changes in whole body protein synthesis after insulin withdrawal is the result of the summation of differential effects of insulin deficiency on the synthesis of specific body proteins. (J. Clin. Invest. 1991. 88:833-840.) Key words: leucine • KIC • amino acids • diabetes • protein metabolism
\end{abstract}

\section{Introduction}

Insulin exposure to rat tissues both in vitro and in vivo decreases in vitro estimates of proteolysis and stimulates in vitro estimates of protein synthesis (1-9). In humans, insulin infusion, in the absence of an exogenous source of amino acids, decreases the plasma concentrations of most essential amino acids (10) and whole body proteolysis (as assessed by decreased rates of leucine appearance) $(11,12)$, but does not increase whole-body protein synthesis (as reflected by decreased rates of

Address reprint requests to Dr. Morey W. Haymond, Nemours Children's Clinic, P.O. Box 5720, Jacksonville, FL 32247.

Received for publication 5 November 1990 and in revised form 21 March 1991.

J. Clin. Invest.

(c) The American Society for Clinical Investigation, Inc. 0021-9738/91/09/0833/08 $\$ 2.00$

Volume 88, September 1991, 833-840 nonoxidative leucine disposal) $(11,12)$. During a combined insulin and amino acid infusion, measures of proteolysis are similarly suppressed, whereas the estimates of protein synthesis are sustained or slightly increased, depending on the experimental conditions and/or the isotope model employed (13-15). In addition, studies employing forearm perfusion (16) and/or muscle biopsy techniques $(17,18)$ in humans support the effcacy of insulin in suppressing rates of proteolysis, but have failed to demonstrate a stimulatory effect of insulin on muscle protein synthesis.

During insulin withdrawal in type 1 diabetic subjects, rates of whole-body proteolysis are increased $(17,19-22)$, an effect consistent with an inhibitory action of insulin on protein breakdown. However, in contrast to in vitro and in vivo results in rats (1-9), insulin withdrawal in humans results in either no change $(20,21)$ or, paradoxically, in an increase in the nonoxidative leucine disposal $(17,19,22)$.

Taken together, these data support a consistent effect of insulin on protein breakdown but the effects of insulin on protein synthesis remain controversial. This lack of agreement on the effects of insulin on protein synthesis could be the result of problems inherent in the assumptions of the isotope model used to estimate protein synthesis (e.g., $\mathrm{CO}_{2}$ fractional recovery is constant) and/or due to the fact that estimates of whole-body protein synthesis in humans reflect the net result of differential effects of insulin (some stimulatory and some inhibitory) on the synthesis of specific proteins. This latter hypothesis is supported by the results of a number of studies demonstrating a selective effect of insulin on the cell concentrations of specific mRNAs and, consequently, on the synthetic rates of individual proteins (23-25). In particular, albumin mRNA concentration and albumin synthesis are increased by insulin, both in vivo in rats $(26,27)$ and in liver cell cultures $(25,28)$, whereas no effect of insulin on fibrinogen synthesis has been observed $(29,30)$. Thus, the metabolic stress induced by insulin deficiency could result in an increase in the synthetic rates of acute phase reactant proteins that could obscure the concomitant decrease in the synthesis of other insulin-sensitive proteins.

Therefore, the present study was designed to determine the effects of insulin withdrawal on $\mathrm{CO}_{2}$ fixation and on the estimated rates of protein synthesis using simultaneous infusions of $\mathrm{NaH}^{13} \mathrm{CO}_{3}$ and $\left[{ }^{14} \mathrm{C}\right]$ leucine infusion, respectively, and to determine the fractional protein synthetic rate of albumin and of the acute reactant phase protein fibrinogen.

\section{Methods}

Materials. Purity and sterility of $\mathrm{L}-\left[1-{ }^{14} \mathrm{C}\right]$ leucine $(>55 \mathrm{mCi} / \mathrm{mmol}$, Amersham Corp., Arlington Heights, IL), and sodium $\left[{ }^{13} \mathrm{C}\right] \mathrm{bi}-$ carbonate (Merck Sharp and Dohme, St. Louis, MO) were determined before use (31). Radio purity of $\left[1-{ }^{14} \mathrm{C}\right]$ leucine was determined by its elution pattern on amino acid analysis (32). Fraction $\mathrm{V}$ albumin, 
thrombin, and $\mathrm{CaCl}_{2}$ were obtained from Sigma Chemical Co., St. Louis, MO.

Protocol. Six type 1 diabetic women without complications or other cardiovascular or renal disease were studied twice in the presence or in the absence of an insulin infusion. All subjects had a normal physical examination, chemistry group, urinalysis, and hematology group before being admitted to the study. Other clinical features of the patients are summarized in Table $\mathrm{I}$. No subject had a C-peptide response $>0.04$ $\mathrm{nM}$ after a 1-mg intravenous glucagon injection. Absence of endogenous insulin secretion was confirmed by lack of increase in the C-peptide concentration during the hyperglycemic component of this study (see Results).

For the $4 \mathrm{~d}$ before the first study, all subjects consumed a known caloric diet in the Clinical Research Center (CRC) of the Mayo Clinic. The diet provided $30-35 \mathrm{cal} \cdot \mathrm{kg}^{-1} \cdot \mathrm{d}^{-1}, 50-60 \%$ carbohydrate, $10-15 \%$ protein, and the remainder as fat. At least $72 \mathrm{~h}$ before the first study all intermediate or long-acting insulin was stopped and the subjects were treated with four daily subcutaneous injections of regular insulin.

On the evening of the admission to the CRC, the patients received their last subcutaneous injection of regular insulin at $16: 30 \mathrm{~h}$ and consumed their standard supper meal at 17:00 h. At 20:00 h, two intravenous catheters were placed in a vein of both forearms, one for the purpose of insulin and/or glucose infusion and the other for frequent plasma glucose determinations (20-30-min intervals).

The insulin infusion was adjusted to maintain the subjects at near euglycemia $(\approx 5.5 \mathrm{mM})$ and was continued until the end of study 1 $(13: 00 \mathrm{~h})$. At 05:00 h on the day of study an intravenous catheter was positioned in retrograde fashion in a dorsal hand vein and the hand placed in a warming box to obtain arterialized venous blood (33). At 06:00 h, study 1 was started and the subjects received a 5-h primed infusion of $\left[{ }^{14} \mathrm{C}\right]$ leucine $\left(10 \mu \mathrm{Ci}, \quad 0.33 \mu \mathrm{Ci} \cdot \mathrm{min}^{-1}\right)$ and of $\left[{ }^{13} \mathrm{C}\right]$ bicarbonate $\left(4.2 \mu \mathrm{mol} / \mathrm{kg}, 0.14 \mu \mathrm{mol} \cdot \mathrm{kg}^{-1} \cdot \mathrm{min}^{-1}\right) .15 \mathrm{ml}$ of blood were drawn for plasma hormone, substrate, amino acid, leucine, and KIC concentrations and leucine and KIC sp act at $-15,0,60,120$, $180,200,220,240,260,280$, and $300 \mathrm{~min} .10 \mathrm{ml}$ of additional blood were withdrawn at 0 and $300 \mathrm{~min}$ for blood hematocrit and determination of the plasma concentrations of albumin, fibrinogen, and catecholamines. Arterialized venous blood gases were determined at 0,180 , and $300 \mathrm{~min}$. Breath samples for measuring the rates of expired total $\mathrm{CO}_{2}$, total ${ }^{14} \mathrm{CO}_{2},{ }^{14} \mathrm{CO}_{2}$ sp act and ${ }^{13} \mathrm{CO}_{2}$ enrichments were collected at -15 , $0,180,200,220,240,260,280$, and $300 \mathrm{~min}$.

Upon completion of study $1(300 \mathrm{~min})$ the isotope and insulin infusions were discontinued, and the subjects were permitted to ambulate freely in the CRC. They consumed their lunch meal but received no insulin. They were subsequently fasted but permitted to drink water ad libitum until the completion of study 2 . The subjects were followed carefully; fluid balance, plasma glucose, and urinary ketone bodies were measured every 2-4 h. Upon appearance of urinary ketones, arterialized venous blood gases were determined and repeated every 3-4 $\mathrm{h}$. When the plasma bicarbonate reached the concentration of $\approx 20 \mathrm{mM}(12 \pm 2 \mathrm{~h}$ after insulin withdrawal), study 2 was initiated and

Table I. Clinical Features of the Diabetic Subjects

\begin{tabular}{cccccc}
\hline Subject & Age & Weight & $\begin{array}{c}\text { Diabetes } \\
\text { duration }\end{array}$ & $\begin{array}{c}\text { Insulin } \\
\text { dosage }\end{array}$ & HBA1 \\
\hline & $y r$ & $k g$ & $y r$ & $U / d$ & $\%$ \\
A & 25 & 63 & 12 & 45 & 12.0 \\
B & 23 & 71 & 8 & 38 & 19.4 \\
C & 20 & 61 & 15 & 43 & 13.1 \\
D & 20 & 56 & 11 & 51 & 12.4 \\
E & 20 & 69 & 4 & 45 & 10.8 \\
F & 21 & 65 & 12 & 62 & 13.5 \\
Mean \pm SEM & $21 \pm 1$ & $64 \pm 2$ & $12 \pm 2$ & $47 \pm 3$ & $13.5 \pm 1.3$ \\
& & & & &
\end{tabular}
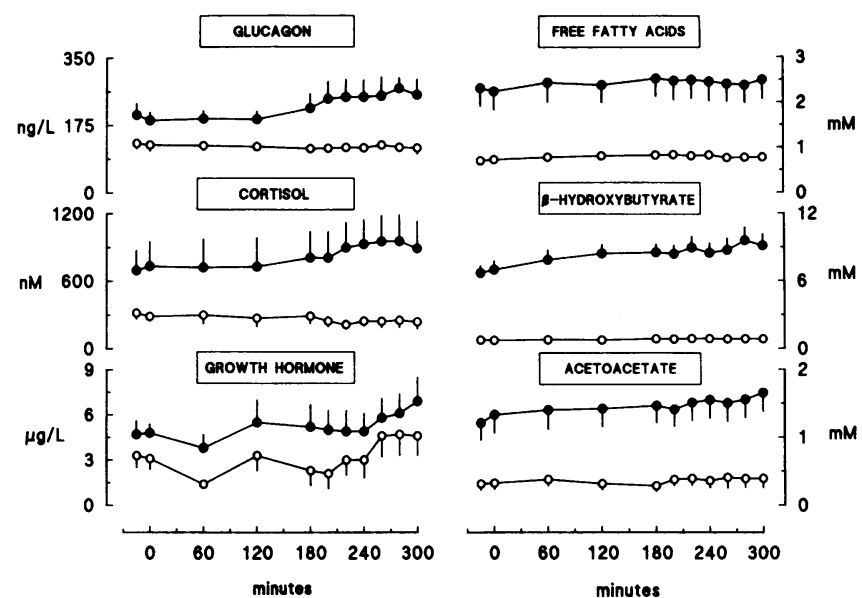

Figure 1. Plasma concentrations of glucagon, cortisol, growth hormone, FFA, and ketone bodies during insulin infusion $(0.21 \pm 0.02$ $\mathrm{mU} \cdot \mathrm{kg}^{-1} \cdot \mathrm{min}^{-1}$; study 1 , open circles) and after insulin withdrawal (study 2 , solid circles) in six type 1 diabetic subjects.

carried out in a fashion identical to that of study 1 with the exception that no insulin was infused and patient hydration was maintained by infusing $0.45 \% \mathrm{NaCl}$ at the rate of $4 \mathrm{ml} \cdot \mathrm{min}^{-1}$. After completion of the study plasma electrolyte concentrations were determined, insulin was infused intravenously and fluid and electrolyte infusions were continued until the mild ketoacidosis was corrected (3-5 h).

Analytical methods. The plasma concentration of glucose (glucose analyzer; Yellow Spring Instrument Co., Yellow Spring, OH), free insulin (34), C-peptide (35), growth hormone (36), cortisol (37), glucagon (38), free fatty acids (39), beta-hydroxybutyrate, and acetoacetate (40) were determined as previously described. Plasma catecholamines were measured through the Mayo Regional Laboratory by HPLC (41). Arterialized venous measurements of $\mathrm{pH}, \mathrm{PCO}_{2}, \mathrm{PO}_{2}$ and bicarbonate were determined by the Mayo Clinic Respiratory Laboratory using an IL-1310 gas analyzer (Instrumentation Laboratory, Inc., Lexington, MA). Blood hematocrit, plasma albumin, and fibrinogen concentrations were measured through the Mayo Clinic General Chemistry and Hematology Laboratories.

Plasma concentration and sp act of KIC and leucine were determined by HPLC as previously described (42). Plasma amino acid concentrations were measured by ion exchange chromatography (model 7300, amino acid analyzer; Beckman Instruments, Inc., Palo Alto, CA) (32). Expired rates of ${ }^{14} \mathrm{CO}_{2}$ were measured by aspirating 2-min collections of expired air through an ethanolamine solution (43). In addition, the sp act of breath ${ }^{14} \mathrm{CO}_{2}$ was determined at each breath sampling time by aspirating expired air through hydroxyde of hyamine (43). The ${ }^{14} \mathrm{C}$ radioactivity in $\mathrm{KIC}$, leucine, and $\mathrm{CO}_{2}$ was determined with a model LS5000 TD series liquid scintillation counter (Beckman Instruments, Inc.).

The sp act of leucine in plasma fibrinogen was determined as previously described (42) with the exception that peak areas were used. Plasma albumin was isolated using the following procedure. Plasma globulins were crudely removed from $2 \mathrm{ml}$ of defibrinated plasma by adding $1.33 \mathrm{ml}$ of a supersaturated ammonium sulfate solution. The supernatant was subsequently extracted with $2 \mathrm{ml}$ of absolute ethanol (44). The ethanol fraction was dried and subsequently analyzed by SDS-PAGE using an overloaded gel and yielded a single large band which comigrated with fraction $\mathrm{V}$ albumin. The purified plasma albumin fraction was subsequently hydrolyzed (at $110^{\circ} \mathrm{C}$ for $72 \mathrm{~h}$ ), and the $\mathrm{sp}$ act of leucine contained in the albumin fraction was analyzed utilizing procedures identical to those employed for the fibrinogen analysis.

${ }^{13} \mathrm{CO}_{2}$ enrichments and $\mathrm{NaH}^{13} \mathrm{CO}_{3}$ infusion rates were determined using an automated isotope ratio mass spectrometer as previously described (45). 
Calculations. The actual rates of $\mathrm{NaH}^{13} \mathrm{CO}_{2}$ infusion were determined as the product of the infusate stable isotope concentration, isotope enrichment, and the pump infusion rate (45). Total $\mathrm{CO}_{2}$ production $\left(\mathrm{mmol} \cdot \mathrm{kg}^{-1} \cdot \mathrm{min}^{-1}\right)$ was calculated by dividing expired ${ }^{14} \mathrm{CO}_{2}$ $\left(\mathrm{dpm} \cdot \mathrm{kg}^{-1} \cdot \mathrm{min}^{-1}\right)$ by the ${ }^{14} \mathrm{CO}_{2} \mathrm{sp}$ act $\left(\mathrm{dpm} \cdot \mathrm{mmol}^{-1}\right)$ as previously described (43). The expired rate of ${ }^{13} \mathrm{CO}_{2}$ was calculated by multiplying the ${ }^{13} \mathrm{CO}_{2}$ enrichment by the total rate of expired $\mathrm{CO}_{2}$ $\left(\mathrm{mmol} \cdot \mathrm{kg}^{-1} \cdot \mathrm{min}^{-1}\right) .{ }^{13} \mathrm{CO}_{2}$ recovery in breath was calculated by dividing the rate of ${ }^{13} \mathrm{CO}_{2}$ expired by the $\mathrm{NaH}^{13} \mathrm{CO}_{2}$ infusion rate. Rates of radiolabeled isotope administration were determined by multiplying the $\mathrm{dpm} \cdot \mathrm{ml}^{-1}$ of infusate by the infusion rate of the pump $\left(\mathrm{ml} \cdot \mathrm{min}^{-1}\right)$. Estimates of whole body leucine metabolism were made at substrate and isotopic steady state between 200 and 300 min using the reciprocal pool model as previously described (31). The rate of leucine oxidation was calculated as previously described $(31)$ using the $\left[{ }^{14} \mathrm{C}\right] \mathrm{KIC}$ sp act and ${ }^{14} \mathrm{CO}_{2}$ expired rate after correcting for the ${ }^{13} \mathrm{CO}_{2}$ recovery determined simultaneously.

The fractional synthetic rate of albumin and fibrinogen was calculated by dividing the rise of leucine $\mathrm{sp}$ act measured hourly $\left(\mathrm{dpm} \cdot \mathrm{mmol}^{-1} \cdot \mathrm{h}^{-1}\right)$ from 3-5 $\mathrm{h}$ by the mean plasma SA of KIC $\left(\mathrm{dpm} \cdot \mathrm{mmol}^{-1}\right)$ during the same period of time (31). The daily fractional synthetic rate was extrapolated by multiplying the previous result by 24 . The measurement of the fractional synthetic rate assumes that $(a)$ labeled and unlabeled leucine are utilized identically in protein synthesis; $(b)$ once synthesized the protein is released into the circulation without being degraded or stored $(46,47) ;(c)$ leucine SA in plasma protein increases linearly during the time course of the isotope infusion (see Fig. 3); (d) plasma $\left[{ }^{14} \mathrm{C}\right] \mathrm{KIC}$ sp act accurately reflects the intrahepatic $\left[{ }^{14} \mathrm{C}\right]$ leucine-tRNA sp act $(48) ;(e)$ over the course of the isotope infusion no significant recycling of labeled nascent proteins occurs from the peripheral extravascular space to the intravascular space (49). By using radioiodinated albumin it has been estimated that 7-10 d are required for a complete equilibration of labeled albumin between the two pools (50). Therefore, we are able only to estimate the fractional rate of the intravascular albumin pool but not that of the total albumin pool. Consequently, valid estimates of the half-life of albumin cannot be obtained. In contrast, only $\approx 20 \%$ of total body fibrinogen is located in the extravascular bed (51). The half-life of plasma fibrinogen was calculated by dividing the natural $\log$ of $2(\ln 2)$ by the fractional synthetic rate.

Statistics. Data are expressed as mean \pm SEM. Comparisons have been carried out using the Wilcoxon nonparametric test for paired observations (52). Values were considered to be significantly different with a $P<0.05$. Linearity of label incorporation into plasma albumin and fibrinogen was tested according to the method suggested by Snedecor and Cochran (53). Model fitting was performed using the general linear procedure of the SAS-STAT package version $6.06(54)$.

\section{Results}

Insulin, C-peptide, and glucose. Overnight insulin infusion preceding study 1 resulted in a mean plasma glucose concentration of $5.9 \pm 0.2 \mathrm{mM}$ between midnight and 6 a.m. During study 1 , insulin was infused at the rate of $0.21 \pm 0.02$ $\mathrm{mU} \cdot \mathrm{kg}^{-1} \cdot \mathrm{min}^{-1}$ and plasma free insulin levels were $37 \pm 1 \mathrm{pM}$, whereas during study 2 plasma free insulin was below limits of the assay (15 pM). Plasma C-peptide concentrations during two studies were superimposable and $<0.03 \mathrm{nM}$. Mean plasma glucose concentration during study 1 was $5.7 \pm 0.2 \mathrm{mM}$, whereas during study 2 it was $16.1 \pm 1 \mathrm{mM}(P<0.03)$.

Bicarbonate and $\mathrm{pH}$. Arterialized venous bicarbonate concentrations decreased $36 \%$ by the end of study 2 in comparison to study 1 (300 min; study $1,25 \pm 0.2 \mathrm{mM}$; study $2,16 \pm 2 \mathrm{mM}$; $P<0.03)$; similarly, blood $\mathrm{pH}$ decreased from $7.40 \pm 0.01$ (mean value of study 1 ) to $7.30 \pm 0.03$ by the end of study $2(P$ $<0.03$ ).
Counterregulatory hormones (Fig. 1). Plasma concentrations of glucagon and cortisol were increased $(P<0.03)$ during the insulin withdrawal study when compared with the insulin infusion study $(P<0.03)$; plasma growth hormone concentration was higher during study 2 but the values were not statistically significant when compared with those of study 1 . Plasma concentrations of catecholamines did not differ between the two studies (epinephrine study $1,163 \pm 26$ vs. $174 \pm 31 \mathrm{pM}$ at 0 and $300 \mathrm{~min}$, respectively; study $2,184 \pm 33$ vs. $201 \pm 43 \mathrm{pM}$ at 0 and $300 \mathrm{~min}, P=\mathrm{NS}$; norepinephrine study $1,1,246 \pm 193$ vs. $1,198 \pm 188 \mathrm{pM}$ at 0 and $300 \mathrm{~min}$; study $2,1426 \pm 224$ vs. $1,476 \pm 196 \mathrm{pM}$, at 0 and $300 \mathrm{~min}, P=\mathrm{NS}$ ).

Free fatty acids (FFA) and ketone bodies (Fig. 1). During insulin withdrawal the plasma concentration of FFA increased $(P<0.03)$ by nearly threefold when compared with that of the insulin infusion study; similarly, plasma concentrations of $\beta$ hydroxybutyrate and acetoacetate were increased $(P<0.03)$ 10-fold and fivefold, respectively.

Amino acids (Table II). The total plasma concentration of the acid-neutral amino acids was similar in both studies. The total concentration of the essential amino acids was increased $(P<0.03)$ during study 2 , whereas that of the nonessential amino acids was decreased $(P<0.03)$ during study 2 when compared with those of study 1 . Most of the increase in the plasma concentration of the essential amino acids after insulin withdrawal was due to increases of the branched chain amino acids (BCAA), whose plasma concentration more than doubled $(P<0.03)$ between studies 1 and 2 . Among the nonessential amino acids no significant difference between the two studies was observed for the plasma cysteine and tyrosine concentrations, whereas all the other amino acids measured showed a significant decrease after insulin withdrawal $(P<0.03)$.

Total $\mathrm{CO}_{2}$ production and ${ }^{13} \mathrm{CO}_{2}$ recovery in breath (Table III). Total $\mathrm{CO}_{2}$ production increased by $13 \%$ during study 2 in comparison with study 1 ; this difference, however, was not statistically significant. The recovery of ${ }^{13} \mathrm{CO}_{2}$ from infused $\mathrm{NaH}^{13} \mathrm{CO}_{3}$ in expired air during the last 100 min of study 1 was $85 \pm 3 \%$, a value not statistically different from that observed during the same time interval of study $2(84 \pm 3 \%)$.

Leucine kinetics (Tables II, III, and Fig. 2). Plasma leucine (Table II) and KIC (Table III) concentrations were stable throughout each of the two studies, although plasma leucine and KIC concentrations were 100 and $20 \%$ higher, respectively, during study 2 when compared with those of study 1 ( $P$ $<0.03$ ).

The infusion rate of radioactive leucine was $9.2 \pm 0.7$ during study 1 , and $11.4 \pm 0.7 \cdot 10^{3} \mathrm{dpm} \cdot \mathrm{Kg}^{-1} \cdot \mathrm{min}^{-1}$ during study 2 . Both plasma concentration and plasma $\left[{ }^{14} \mathrm{C}\right] \mathrm{KIC}$ sp act were at near steady over the last $100 \mathrm{~min}$ of both studies 1 and 2 (Table III).

Leucine rate of appearance was increased $(P<0.03)$ by $\approx 35 \%\left(1.85 \pm 0.12\right.$ vs. $\left.1.37 \pm 0.12 \mu \mathrm{mol} \cdot \mathrm{kg}^{-1} \cdot \mathrm{min}^{-1}\right)$ during insulin withdrawal when compared with the insulin infusion study (Fig. 2). Concomitantly the rate of leucine oxidation was increased $(P<0.03) 100 \%$ during insulin withdrawal $\left(0.54 \pm 0.08\right.$ vs. $\left.0.24 \pm 0.03 \mu \mathrm{mol} \cdot \mathrm{kg}^{-1} \cdot \mathrm{min}^{-1}\right)$; whereas the rate of nonoxidative leucine disposal was not significantly higher $(P$ $=0.21$ ), during insulin withdrawal (study $1,1.12 \pm 0.11$ vs. study $2,1.31 \pm 0.08 \mu \mathrm{mol} \cdot \mathrm{kg}^{-1} \cdot \mathrm{min}^{-1}$ ).

Plasma concentrations and fractional synthetic rates of albumin and fibrinogen (Table IV, Fig. 3). Plasma albumin concentration during the two studies did not change (4.1 \pm 0.2 vs. 
Table II. Plasma Concentration of Acid-Neutral Amino Acids during Insulin Infusion $\left(0.21 \pm 0.02 \mathrm{mU} \cdot \mathrm{kg}^{-1} \cdot \mathrm{min}^{-1}\right.$, Study 1) and after Insulin Withdrawal (Study 2) in Six Type 1 Diabetic Subjects

\begin{tabular}{|c|c|c|c|c|c|c|}
\hline \multirow[b]{2}{*}{ Hours of study } & \multicolumn{3}{|c|}{ Insulin replacement } & \multicolumn{3}{|c|}{ Insulin withdrawal } \\
\hline & 0 & 3 & 5 & 0 & 3 & 5 \\
\hline & $\mu m$ & $\mu m$ & $\mu m$ & $\mu m$ & $\mu m$ & $\mu m$ \\
\hline Aspartate & $5 \pm 1$ & $5 \pm 1$ & $4 \pm 1$ & $4 \pm 1$ & $4 \pm 1$ & $4 \pm 1$ \\
\hline Threonine & $90 \pm 8$ & $87 \pm 10$ & $82 \pm 11$ & $77 \pm 10$ & $68 \pm 8$ & $62 \pm 8$ \\
\hline Serine & $102 \pm 4$ & $103 \pm 6$ & $98 \pm 6$ & $82 \pm 11$ & $71 \pm 9$ & $70 \pm 10$ \\
\hline Glutamate & $51 \pm 6$ & $55 \pm 4$ & $54 \pm 4$ & $28 \pm 4$ & $23 \pm 3$ & $37 \pm 7$ \\
\hline Proline & $135 \pm 16$ & $130 \pm 18$ & $134 \pm 21$ & $112 \pm 19$ & $107 \pm 19$ & $97 \pm 17$ \\
\hline Glycine & $192 \pm 9$ & $196 \pm 8$ & $196 \pm 8$ & $140 \pm 20$ & $115 \pm 11$ & $126 \pm 19$ \\
\hline Alanine & $212 \pm 25$ & $192 \pm 26$ & $199 \pm 29$ & $172 \pm 14$ & $180 \pm 17$ & $187 \pm 22$ \\
\hline Valine & $188 \pm 6$ & $180 \pm 5$ & $172 \pm 7$ & $320 \pm 14$ & $327 \pm 19$ & $319 \pm 15$ \\
\hline Cysteine & $12 \pm 3$ & $12 \pm 3$ & $11 \pm 3$ & $12 \pm 2$ & $13 \pm 3$ & $14 \pm 3$ \\
\hline Methionine & $14 \pm 2$ & $13 \pm 1$ & $13 \pm 1$ & $14 \pm 2$ & $11 \pm 1$ & $13 \pm 1$ \\
\hline Isoleucine & $55 \pm 3$ & $51 \pm 3$ & $47 \pm 4$ & $127 \pm 9$ & $124 \pm 11$ & $119 \pm 8$ \\
\hline Leucine & $105 \pm 4$ & $100 \pm 4$ & $91 \pm 6$ & $222 \pm 13$ & $219 \pm 17$ & $211 \pm 13$ \\
\hline Tyrosine & $36 \pm 3$ & $31 \pm 2$ & $28 \pm 4$ & $43 \pm 3$ & $37 \pm 3$ & $35 \pm 3$ \\
\hline Phenylalanine & $33 \pm 2$ & $37 \pm 2$ & $33 \pm 2$ & $45 \pm 4$ & $40 \pm 3$ & $26 \pm 3$ \\
\hline Essential AA & $485 \pm 15$ & $468 \pm 19$ & $437 \pm 27$ & $801 \pm 30$ & $787 \pm 42$ & $760 \pm 30$ \\
\hline Nonessential AA & $743 \pm 58$ & $722 \pm 57$ & $721 \pm 62$ & $518 \pm 69$ & $458 \pm 63$ & $477 \pm 65$ \\
\hline Total AA & $1228 \pm 62$ & $1190 \pm 71$ & $1158 \pm 84$ & $1320 \pm 54$ & $1244 \pm 89$ & $1237 \pm 59$ \\
\hline
\end{tabular}

$4.1 \pm 0.2 \mathrm{~g} / \mathrm{dl}$ at 0 and $300 \mathrm{~min}$ of study 1 , respectively; $4.2 \pm 0.1$ vs. $4.3 \pm 0.2 \mathrm{~g} / \mathrm{dl}$ at 0 and $300 \mathrm{~min}$ of study $2, P=\mathrm{NS}$ ). Similarly no change in the plasma fibrinogen concentration (199 $\pm 29 \mathrm{vs}$. $208 \pm 26 \mathrm{mg} / \mathrm{dl}$ at 0 and $300 \mathrm{~min}$ of study 1 , respectively; $205 \pm 24$ vs. $201 \pm 26 \mathrm{mg} / \mathrm{dl}$ at 0 and $300 \mathrm{~min}$ of study $2, P=\mathrm{NS}$ ) or in blood hematocrit (study $1,45 \pm 1$ vs. $44 \pm 1 \%$ at 0 and 300 min, respectively; study $2,44 \pm 1$ vs. $43 \pm 2 \%$ at 0 and $300 \mathrm{~min}$, respectively) was observed during or between the two studies.

Leucine sp act in plasma albumin and fibrinogen increased linearly from 60 to $300 \mathrm{~min}(P<0.01)$. A straight line fit was

Table III. ${ }^{14} \mathrm{CO}_{2}$ Excretion, Specific Activity, Production and Recovery in Breath, Plasma KIC Concentration and Specific Activity during Study 1 (Insulin Infusion) and Study 2 (Insulin Withdrawal) in Six Type 1 Diabetic Subjects

\begin{tabular}{|c|c|c|c|c|c|c|}
\hline Minutes & 200 & 220 & 240 & 260 & 280 & 300 \\
\hline \multicolumn{7}{|c|}{$\begin{array}{l}{ }^{14} \mathrm{CO}_{2} \text { excretion } \\
\quad\left(10^{2} \mathrm{dpm} \cdot \mathrm{kg}^{-1} \cdot \mathrm{min}^{-1}\right)\end{array}$} \\
\hline Study 1 & $12.3 \pm 1.4$ & $12.8 \pm 1.9$ & $13.6 \pm 1.7$ & $13.8 \pm 1.7$ & $14.4 \pm 1.6$ & $13.9 \pm 1.6$ \\
\hline Study 2 & $26.0 \pm 3.5^{*}$ & $26.6 \pm 3.6^{*}$ & $28.4 \pm 4.0^{*}$ & $28.9 \pm 3.0^{*}$ & $28.6 \pm 3.2^{*}$ & $29.0 \pm 3.0^{*}$ \\
\hline \multicolumn{7}{|c|}{${ }^{14} \mathrm{CO}_{2} \mathrm{SA}\left(10^{3} \mathrm{dpm} \cdot \mathrm{nmol}^{-1}\right)$} \\
\hline Study 1 & $9.8 \pm 0.9$ & $10.3 \pm 0.9$ & $10.2 \pm 0.8$ & $10.3 \pm 0.9$ & $10.9 \pm 0.9$ & $10.8 \pm 0.8$ \\
\hline Study 2 & $16.2 \pm 1.6^{*}$ & $16.5 \pm 1.7^{*}$ & $17.0 \pm 1.6^{*}$ & $17.9 \pm 1.7^{*}$ & $18.3 \pm 1.9^{*}$ & $17.9 \pm 2.2 *$ \\
\hline \multicolumn{7}{|c|}{$\begin{array}{l}\mathrm{CO}_{2} \text { production } \\
\quad\left(\mu \mathrm{mol} \cdot \mathrm{kg}^{-1} \cdot \mathrm{min}^{-1}\right)\end{array}$} \\
\hline Study 1 & $125 \pm 5$ & $124 \pm 8$ & $133 \pm 8$ & $133 \pm 9$ & $132 \pm 8$ & $129 \pm 9$ \\
\hline Study 2 & $145 \pm 11$ & $146 \pm 11$ & $152 \pm 14$ & $146 \pm 13$ & $143 \pm 15$ & $147 \pm 12$ \\
\hline \multicolumn{7}{|l|}{${ }^{13} \mathrm{CO}_{2}$ recovery $(\%)$} \\
\hline Study 1 & $80 \pm 2$ & $82 \pm 3$ & $84 \pm 4$ & $88 \pm 3$ & $88 \pm 4$ & $87 \pm 5$ \\
\hline Study 2 & $80 \pm 3$ & $81 \pm 3$ & $84 \pm 5$ & $83 \pm 3$ & $87 \pm 5$ & $88 \pm 4$ \\
\hline \multicolumn{7}{|l|}{ Plasma KIC $(\mu M)$} \\
\hline Study 1 & $26 \pm 3$ & $26 \pm 3$ & $27 \pm 3$ & $29 \pm 3$ & $29 \pm 4$ & $28 \pm 4$ \\
\hline Study 2 & $32 \pm 5$ & $34 \pm 5$ & $31 \pm 4$ & $35 \pm 4$ & $35 \pm 6$ & $32 \pm 5$ \\
\hline \multicolumn{7}{|l|}{$\begin{array}{l}\text { Plasma KIC SA } \\
\qquad\left(\mathrm{dpm} \cdot \mathrm{nmol}^{-1}\right)\end{array}$} \\
\hline Study 1 & $6.8 \pm 0.4$ & $6.5 \pm 0.4$ & $6.7 \pm 0.4$ & $6.8 \pm 0.4$ & $7.0 \pm 0.5$ & $6.9 \pm 0.5$ \\
\hline Study 2 & $6.6 \pm 0.5$ & $6.1 \pm 0.6$ & $6.0 \pm 0.5$ & $6.5 \pm 0.5$ & $6.2 \pm 0.5$ & $6.0 \pm 0.4$ \\
\hline
\end{tabular}

${ }^{*} P<0.03$ vs. study 1 . 

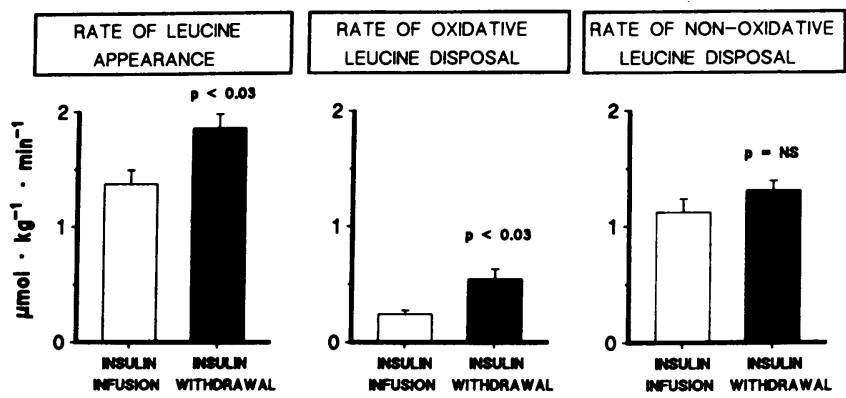

Figure 2. Rates of leucine appearance, of oxidative and of nonoxidative leucine disposal during insulin infusion $(0.21 \pm 0.02$ $\mathrm{mU} \cdot \mathbf{k g}^{-1} \cdot \mathrm{min}^{-1}$; study 1 , open bars) and after insulin withdrawal (study 2 , solid bars) in six type 1 diabetic subjects.

adequate to describe the time course of label incorporation into the two proteins for each subject's data during both studies. Leucine sp act in plasma albumin and fibrinogen at the end of study 1 was $134 \pm 14$ and $256 \pm 20 \cdot 10^{3} \mathrm{dpm} \cdot \mathrm{nmol}^{-1}$, respectively. Basal leucine sp act of study 2 in plasma albumin and fibrinogen was $139 \pm 18$ and $301 \pm 29 \cdot 10^{3} \mathrm{dpm} \cdot \mathrm{nmol}^{-1}$, respectively. The slope of increase of albumin and fibrinogen sp act after the label infusion of study 1 was $0.0077 \pm 0.001$ and $0.0623 \pm 0.006 \cdot 10^{3} \mathrm{dpm} \cdot \mathrm{nmol}^{-1} \cdot \mathrm{min}^{-1}$. Assuming that this slope continued over the subsequent $5 \mathrm{~h}$ of study 2 , it is evident that when compared with the actual slopes observed during study 2 (albumin $0.319 \pm 0.06$, fibrinogen $1.454 \pm 0.2 \cdot 10^{3}$ $\mathrm{dpm} \cdot \mathrm{nmol}^{-1} \cdot \mathrm{min}^{-1}$ ) the baseline contribution to these results would be negligible, indicating that the albumin and fibrinogen fractional synthetic rates of the two studies can be compared in a valid fashion.

The estimated daily fractional albumin synthetic rate during the insulin infusion study was $9.9 \pm 1.2 \%$ and decreased $(P$ $<0.03$ ) by $29 \%$ during the insulin withdrawal study $(7.0 \pm 2.6 \%)$.

The estimated daily fractional fibrinogen synthetic rate during the insulin infusion study was $22 \pm 2 \%$ and increased $(P$ $<0.03$ ) to $33 \pm 5 \%$ during the insulin withdrawal study, an increase of nearly $50 \%$. The calculated half-life of plasma fibrinogen during the insulin infusion study was $3.1 \pm 0.4 \mathrm{~d}$ and decreased $(P<0.03)$ to $2.1 \pm 0.3 \mathrm{~d}$ after insulin withdrawal.
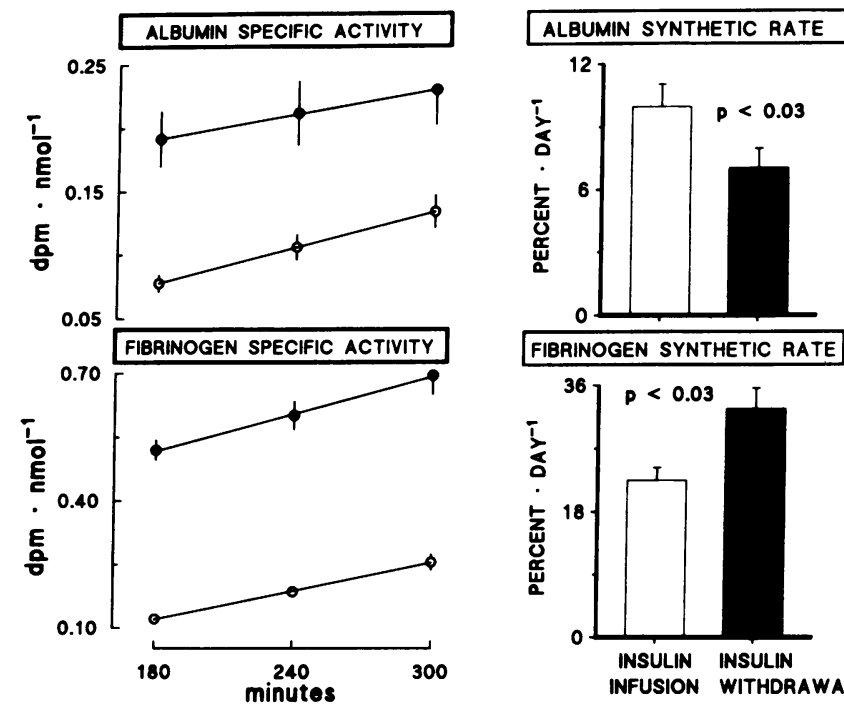

FIBRINOGEN SYNTHETIC RATE

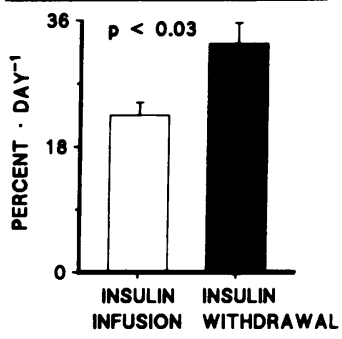

Figure 3. Albumin and fibrinogen sp act during insulin infusion $\left(0.21 \pm 0.02 \mathrm{mU} \cdot \mathrm{kg}^{-1} \cdot \mathrm{min}^{-1}\right.$; study 1, open circles $)$ and after insulin withdrawal (study 2, solid circles) in six type 1 diabetic subjects and calculated daily albumin and fibrinogen fractional synthetic rates during study 1 (open bars) and study 2 (solid bars).

\section{Discussion}

The present study demonstrates that short-term insulin deficiency in type 1 diabetic subjects leads to an increase in the rates of whole body proteolysis and of leucine oxidation, but has no effect on the estimated rate of whole body protein synthesis. This latter result would suggest that insulin does not regulate protein synthesis in humans. However, during insulin deficiency, we detected a significant decrease in the fractional synthetic rate of albumin and a concomitant significant increase in that of fibrinogen. These data indicate a differential effect of insulin deficiency on the fractional synthetic rate of two hepatically synthesized plasma proteins. Thus, the observed absence of changes in the estimated whole body protein synthetic rate during insulin deficiency was most likely due to a concomitant increase in the synthesis of some body proteins

Table IV. Slopes of Plasma Albumin and Fibrinogen Specific Activities, Mean Plasma KIC Specific Activities (180-300 min) and Albumin and Fibrinogen Fractional Synthetic Rates during Study 1 (Insulin Infusion) and Study 2 (Insulin Withdrawal) in Six Type 1 Diabetic Subjects

\begin{tabular}{|c|c|c|c|c|c|c|c|c|c|c|}
\hline \multirow[b]{3}{*}{ Subject } & \multicolumn{4}{|c|}{ SA increase $(180-300 \mathrm{~min})$} & & & \multicolumn{4}{|c|}{ Fractional synthetic rate } \\
\hline & \multicolumn{2}{|c|}{ Albumin } & \multicolumn{2}{|c|}{ Fibrinogen } & \multicolumn{2}{|c|}{ Plasma KIC SA } & \multicolumn{2}{|c|}{ Albumin } & \multicolumn{2}{|c|}{ Fibrinogen } \\
\hline & Study 1 & Study 2 & Study 1 & Study 2 & Study 1 & Study 2 & Study 1 & Study 2 & Study 1 & Study 2 \\
\hline & \multicolumn{4}{|c|}{$10^{3} \mathrm{dpm} \cdot \mathrm{nmol}^{-1} \cdot \mathrm{min}^{-1}$} & \multicolumn{2}{|c|}{$d p m \cdot n m o l^{-1}$} & \multicolumn{4}{|c|}{$\% \cdot d^{-1}$} \\
\hline $\mathbf{A}$ & 0.496 & 0.259 & 1.043 & 1.119 & 8.26 & 7.30 & 8.6 & 5.1 & 18 & 22 \\
\hline $\mathrm{C}$ & 0.475 & 0.239 & 1.422 & 2.117 & 7.03 & 6.15 & 9.7 & 5.6 & 29 & 50 \\
\hline D & 0.700 & 0.569 & 1.279 & 2.296 & 7.05 & 7.74 & 14.3 & 10.6 & 26 & 43 \\
\hline $\mathbf{E}$ & 0.477 & 0.290 & 0.822 & 1.358 & 7.31 & 7.38 & 9.4 & 5.7 & 16 & 26 \\
\hline $\mathbf{F}$ & 0.211 & 0.146 & 1.011 & 0.931 & 5.25 & 4.10 & 5.8 & 5.1 & 28 & 33 \\
\hline
\end{tabular}

All slopes of plasma albumin and fibrinogen sp act are statistically significant $(P<0.01)$. 
and to a concomitant and offsetting decrease in the synthetic rate of others.

In the present study, as has already been observed by others $(18,20,21)$ insulin deficiency resulted in an increase in the plasma concentration of the essential amino acids, primarily the BCAA, attributable to the increased rate of whole body proteolysis observed after insulin withdrawal $(\approx 35 \%)$, because estimates of whole body protein synthesis did not change. In contrast to the essential amino acids, the plasma concentration of the nonessential amino acids significantly decreased after insulin withdrawal. Because proteolysis was increased, this reduction in the plasma concentration of the nonessential amino acids was most likely due to decreased de novo synthesis and/or increased rates of utilization. The increase in the rate of utilization of the nonessential amino acids is consistent with increased gluconeogenis, known to occur with insulin deficiency $(55,56)$.

During insulin deficiency, the rate of leucine oxidation was increased more than $100 \%$. This observation is consistent with other reports both in vitro (57) and in vivo (58) that increased concentration of leucine and KIC are associated with an activation of the branched chain $\alpha$-ketoacid dehydrogenase and with increased rates of oxidation of the carbon skeleton of leucine. Extrapolating the increase in leucine oxidation to other amino acids, these data are consistent with the nitrogen wasting known to occur in poorly controlled diabetics (59) and the increased use of amino acids as an energy source as has been shown in iatrogenically-induced protein catabolism associated with the administration of glucocorticosteroids in humans (60).

Leucine oxidation is calculated by dividing the rate of labeled $\mathrm{CO}_{2}$ expired in breath by the precursor pool sp act (31). Because part of the labeled $\mathrm{CO}_{2}$ generated from the oxidation of leucine is retained in the body during the course of the study, the rate of expired labeled $\mathrm{CO}_{2}$ must be corrected for such fixation and has been estimated in normal subjects to be $19 \%$ (61). In previous studies in which the effects of insulin withdrawal were compared with those of insulin replacement (17, 19-22) the fractional $\mathrm{CO}_{2}$ recovery was not determined and was assumed to be constant. During an infusion of $\left[{ }^{13} \mathrm{C}\right] \mathrm{bi}$ carbonate, recovery of tracer in breath increased linearly with $\mathrm{CO}_{2}$ production (62; Horber, F., and $\mathrm{M}$. Haymond, unpublished data), suggesting that increased $\mathrm{CO}_{2}$ production, as might occur in ketoacidosis after insulin withdrawal, could result in an increase in the fractional $\mathrm{CO}_{2}$ recovery. Failure to account for this could lead to overestimate leucine oxidation and to underestimate protein synthesis. However, because $\mathrm{CO}_{2}$ production was slightly but not significantly increased in the present study this cannot be a factor. Conversely, $\mathrm{CO}_{2}$ recovery might have been decreased during insulin deficiency as a result of a greater fractional fixation of labeled $\mathrm{CO}_{2}$ due to increased gluconeogenesis during insulin deficiency $(55,56)$. This possibility is indirectly supported by the observation that factors known to suppress gluconeogenesis, such as feeding (62), decrease $\mathrm{CO}_{2}$ recovery, whereas gluconeogenic stimuli, such as fasting (62) or steroid administration (Horber, F., B. Beaufrere, and $M$. Haymond, unpublished data), increase it.

In the present study, the fractional $\mathrm{CO}_{2}$ recovery did not significantly change under the two experimental conditions. The absence of significant changes in the fraction of $\mathrm{CO}_{2}$ fixed between the insulin replacement and withdrawal protocols suggest that errors in $\mathrm{CO}_{2}$ fixation could not be used to explain the failure of previous studies $(17,19-22)$ to observe a decrease in whole body protein synthesis during insulin deficiency or withdrawal.

Insulin deficiency induced both in vitro and in vivo significantly decreases in vitro measures of protein synthesis and, conversely, insulin administration stimulates it $(1,2,4-9,63)$. Insulin regulates protein synthesis at both the translational and transcriptional levels. At the translational level insulin stimulates peptide chain initiation factors $(1,9)$ and increases the number of ribosomes as evidenced by increased ribosomal RNA $(4,6)$. At the transcriptional level insulin acts by either increasing $(23,25)$ or decreasing $(23,24)$ the cell content of specific mRNAs. These latter observations indicate that insulin can selectively stimulate the synthesis of some proteins and inhibit that of others (23). In humans, measurements of whole body protein synthesis reflect the sum of the effects of insulin on the synthetic rates of all body proteins; therefore, during insulin deficiency a reduction in the synthesis of some proteins which anabolically respond to insulin could be obscured by a concomitant increase in the synthesis of other proteins whose production may be inhibited by insulin or stimulated by other factors.

The stimulatory effects of insulin on albumin synthesis have been clearly demonstrated both in liver cell cultures $(25$, $28)$ and in vivo in rats $(26,27)$. In diabetic rats, insulin deficiency significantly decreased the intracellular concentration of albumin mRNA with a resultant decrease of albumin synthesis (27). Subsequent insulin administration increased both albumin mRNA concentration and albumin synthesis, which were completely normalized after $3 \mathrm{~d}$ of treatment (27). In contrast, fibrinogen synthesis in vitro is not affected by insulin administration $(29,30)$, whereas it is increased by other hormones such as corticosteroids and triiodothyronine (29) and by interleukin-6 (64), a monokine that appears to play a key role in determining the response to stress of acute phase reactant proteins (64).

In our diabetic subjects during insulin replacement the calculated daily fractional synthetic rate of albumin $(10 \pm 1 \%)$ and that of fibrinogen $(22 \pm 2 \%)$ are comparable with those recently reported in normal subjects during rest (65) and to those recently obtained in normal subjects in our laboratory (unpublished data). Also the half-life of fibrinogen $(3.1 \pm 0.4 \mathrm{~d})$ in the insulin-treated diabetic subjects was not different from that previously calculated in normal subjects (3-4 d) using other techniques (66-69). Short-term insulin withdrawal resulted in a $29 \%$ decrease in the albumin synthetic rate and in a concomitant $50 \%$ increase in the fibrinogen synthetic rate. Since between the two studies and in the time frame of the same study no change occurred in the hematocrit or in the concentration of either plasma albumin or fibrinogen, these changes in the calculated fractional synthetic rates are indicative of the relative changes in their synthetic rates.

In the present study we demonstrate, for the first time, that in humans reciprocal changes in the synthetic rate of these two hepatic proteins occurred under conditions of insulin deficiency. However, we cannot exclude that factors other than insulin deficiency per se might have been responsible for the results observed. Insulin withdrawal was associated with a significant increase in the plasma concentration of cortisol, glucagon, FFA, ketone bodies, and essential amino acids which have been reported to affect leucine and protein metabolism $(13,15$, $56,58,70-75)$. However, in absence of other hormonal inter- 
actions in vitro, insulin deficiency decreased the rate of albumin gene transcription and, conversely, insulin replacement increased it (28). In contrast, no effect of insulin on fibrinogen synthesis has been reported in vitro $(29,30)$, suggesting that the increase in fibrinogen synthetic rate observed in the present study was due to factors other than insulin deficiency. Other hormones such as cortisol and triiodothyronine are potent in vitro stimulators of fibrinogen synthesis (29), as well as interleukin-6 (64). Thus, the increase in the fractional synthetic rate of fibrinogen is consistent with the higher plasma cortisol concentration observed during insulin deficiency.

If our finding for albumin and fibrinogen synthesis can be extrapolated, populations of proteins throughout the body may be stimulated by insulin, whereas others may be unaffected or inhibited by insulin. This alone could account for the failure to demonstrate significant changes in whole body estimates of protein synthesis during insulin deficiency. Other than in rat liver (23), a selective effect of insulin on protein synthesis has also been reported in rat cardiac muscle, where insulin deficiency was associated with a decreased transcription of 11 mRNA species and with a concomitant increased transcription of eight other specific mRNAs (76). Studies in humans using organ balance $(16)$ and muscle biopsies $(17,18)$ have failed to demonstrate an effect of insulin on whole muscle tissue protein synthesis. Therefore, future studies in humans must address the effect of insulin on the synthesis of specific muscle proteins.

\section{Acknowledgments}

The invaluable help of Dr. Paolo Reboldi for statistical analysis and the skillful technical assistance of Joan Aikens are gratefully acknowledged.

Dr. P. De Feo is the recipient of an International Research Fellowship from the Fogarty International Center (NIH, 1FOSTWO 04101). This work was supported by the United States Public Health Grant DK-26989, the Minnesota American Diabetes Association, and the Mayo and Nemours Foundations.

\section{References}

1. Jefferson, L. S. 1980 . Role of insulin in the regulation of protein synthesis. Diabetes. 29:487-496.

2. Kimball, S. R., and L. S. Jefferson. 1988. Cellular mechanisms involved in the action of insulin on protein synthesis. Diabetes Metab. Rev. 4:773-787.

3. Mortimore, G. E., and C. E. Mondon. 1970. Inhibition by insulin of valine turnover in liver. J. Biol. Chem. 245:2375-2383.

4. Pain, V. M., and P. J. Garlick. 1974. Effect of streptozotocin diabetes and insulin treatment on the rate of protein synthesis in tissues of the rat in vivo. J. Biol. Chem. 249:4510-4514.

5. Neely, A. N., J. R. Cox, and S. A. Fortney. 1977. Alterations of lysosomal size and density during rat liver perfusion. Suppression by insulin and amino acids. J. Biol. Chem. 252:6948-6954.

6. Flaim, K. E., M. E. Copenhaver, and L. S. Jefferson. 1980. Effects of diabetes on protein synthesis in fast- and slow-twitch rat skeletal muscle. Am. J. Physiol. 239:E88-E95.

7. Airhart, J., J. A. Arnold, W. S. Stirewalt, and R. B. Low. 1982. Insulin stimulation of protein synthesis in cultured skeletal and cardiac muscle cells. $\mathrm{Am}$. J. Physiol. 243:C81-C86.

8. Stirewalt, W. S., and R. B. Low. 1983. Effects of insulin in vitro on protein turnover in rat epitrochlearis muscle. Biochem. J. 210:323-330.

9. Buse, M. G., I. R. Cheema, M. Owens, B. E. Ledford, and R. A. Galbraith. 1984. Muscle protein synthesis: regulation of a translational inhibitor. $\mathrm{Am}$. J. Physiol. 246:E510-E515.

10. Fukagawa, N. K., K. L. Minaker, V. R. Young, and J. W. Rowe. 1986. Insulin dose-dependent reductions in plasma amino acids in man. Am. J. Physiol. 250:E13-E17.

11. Fukagawa, N. K., K. L. Minaker, J. W. Rowe, M. N. Goodman, D. E. Matthews, D. M. Bier, and V. R. Young. 1985. Insulin-mediated reduction of whole body protein breakdown: dose-response effects on leucine metabolism in postabsorptive men. J. Clin. Invest. 76:2306-2311.

12. Tessari, P., R. Trevisan, S. Inchiostro, G. Biolo, R. Nosadini, S. V. De Kreutzenberg, E. Duner, A. Tiengo, and G. Crepaldi. 1986. Dose-response curves of effects of insulin on leucine kinetics in humans. Am. J. Physiol. 251:E334E342.

13. Castellino, P., L. Luzi, D. C. Simonson, M. Haymond, and R. A. DeFronzo. 1987. Effect of insulin and plasma amino acid concentrations on leucine metabolism in man: role of substrate availability on estimates of whole body protein synthesis. J. Clin. Invest. 80:1784-1793.

14. Tessari, P., S. Inchiostro, G. Biolo, R. Trevisan, G. Fantin, M. C. Marescotti, E. Iori, A. Tiengo, and G. Crepaldi. 1987. Differential effects of hyperinsulinemia and hyperaminoacidemia on leucine-carbon metabolism in vivo: evidence for distinct mechanisms in regulation of net amino acid deposition. J. Clin. Invest. 79:1062-1069.

15. Luzi, L., P. Castellino, D. C. Simonson, A. S. Petrides, and R. A. DeFronzo. 1990. Leucine metabolism in IDDM: role of insulin and substrate availability. Diabetes. 39:38-48.

16. Gelfand, R. A., and E. J. Barrett. 1987. Effect of physiologic hyperinsulinemia on skeletal muscle protein synthesis and breakdown in man. J. Clin. Invest. 80:1-6.

17. Pacy, P. J., K. S. Nair, C. Ford, and D. Halliday. 1989. Failure of insulin infusion to stimulate fractional muscle protein synthesis in type 1 diabetic patients. Anabolic effect of insulin and decreased proteolysis. Diabetes. 38:618-624.

18. Bennet, W. M., A. A. Connacher, K. Smith, R. T. Jung, and M. J. Rennie. 1990. Inability to stimulate skeletal muscle or whole body protein synthesis in type 1 (insulin-dependent) diabetic patients by insulin-plus-glucose during amino acid infusion: studies of incorporation and turnover of tracer $L-\left[1-{ }^{13} \mathrm{C}\right]$ leucine. Diabetologia. 33:43-51.

19. Nair, K. S., J. S. Garrow, C. Ford, R. F. Mahler, and D. Halliday. 1983. Effect of poor diabetic control and obesity on whole body protein metabolism in man. Diabetologia. 25:400-403.

20. Robert, J. J., B. Beaufrere, J. Koziet, J. F. Desjeux, D. M. Bier, V. R Young, and H. Lestradet. 1985. Whole body de novo amino acid synthesis in type 1 (insulin-dependent) diabetes studied with stable isotope-labelled leucine, alanine, and glycine. Diabetes. 34:67-73.

21. Umpleby, A. M., M. A. Boroujerdi, P. M. Brown, E. R. Carson, and P. H Sönksen. 1986. The effect of metabolic control on leucine metabolism in type 1 (insulin-dependent) diabetic patients. Diabetologia. 29:131-141.

22. Nair, K. S., G. C. Ford, and D. Halliday. 1987. Effect of intravenous insulin treatment on in vivo whole body leucine kinetics and oxygen consumption in insulin-deprived type 1 diabetic patients. Metabolism. 36:491-495.

23. Dillmann, W. H. 1988. Diabetes mellitus-induced changes in the concentration of specific mRNAs and proteins. Diabetes Metab. Rev. 4:789-797.

24. Granner, D. K., T. Andreone, K. Sasaki, and E. Beale. 1983. Inhibition of transcription of the phosphoenolpyruvate carboxykinase gene by insulin. Nature (Lond.) 305:549-551

25. Flaim, K. E., S. M. Hutson, C. E. Lloyd, J. M. Taylor, R. Shiman, and L. S. Jefferson. 1985. Direct effect of insulin on albumin gene expression in primary cultures of rat hepatocytes. Am. J. Physiol. 249:E447-E453.

26. Peavy, D. E., J. M. Taylor, and L. S. Jefferson. 1978. Correlation of albumin production rates and albumin mRNA levels in livers in normal, diabetic and insulin-treated diabetic rats. Proc. Natl. Acad. Sci. USA 75:5879-5883.

27. Peavy, D. E., J. M. Taylor, and L. S. Jefferson. 1985. Time course of changes in albumin synthesis and mRNA in diabetic and insulin-treated diabetic rats. Am. J. Physiol. 248:E656-E663.

28. Lloyd, C. E., J. E. Kalinyak, S. M. Hutson, and L. S. Jefferson. 1987 Stimulation of albumin gene transcription by insulin in primary cultures of rat hepatocytes. Am. J. Physiol. 252:C205-C214.

29. Grieninger, G., P. W. Plant, J. Liang, R. G. Kalb, D. Amrani, M. W. Mosesson, K. M. Hertzbergh, and J. Pindyck. 1983. Hormonal regulation of fibrinogen synthesis in cultured hepatocytes. Ann. NY Acad. Sci. 408:469-489.

30. Alessi, M. C., I. Juhan-Vague, T. Kooistra, P. J. Declerck, and D. Collen. 1988. Insulin stimulates the synthesis of plasminogen activator inhibitor 1 by the human hepatocellular cell line Hep G2. Thromb. Haemostas. 60:491-494.

31. Schwenk, W. F., B. Beaufrere, and M. W. Haymond. 1985. Use of reciprocal pool specific activities to model leucine metabolism in humans. Am. J. Physiol. 249:E646-E650.

32. Stacey-Schmidt, C., P. Berg, and M. W. Haymond. 1982. Use of D-glucosamine acid as an internal standard in simple column accelerated amino acid analysis of physiological fluids. Anal. Biochem. 123:74-77.

33. McGuire, E., J. Helderman, J. Tobin, R. Andres, and M. Berman. 1976. Effects of arterial venous sampling on analysis of glucose kinetics in man. J. Appl. Physiol. 41:565-573.

34. Nagakawa, S., H. Nakayama, T. Sasaki, K. Yoshino, Y. Y. Yu, K. Shinozaki, S. Aoki, and K. Mashimo. 1973. A simple method for the determination of serum free insulin levels in insulin-treated patients. Diabetes. 22:590-600.

35. Heding, L. 1975. Radioimmunological determination of human C-peptide in serum. Diabetologia. 11:541-548.

36. Peake, G. 1974. Growth hormone. In Methods of Hormone Radioimmu- 
noassay. B. Jaffe and H. Behrman, editors. Academic Press, Inc., New York. 103-121.

37. Beitins, I. Z., and S. Reid. 1970. Comparison of competitive protein-binding radioimmunoassay of cortisol to double-isotope dilution and Porter Silber method. Steroids. 15:765-776.

38. Faloona, G., and R. Unger. 1974. Glucagon. In Methods of Hormone Radioimmunoassay. B. Jaffe and H. Behrman, editors. Academic Press, Inc. New York. 317-330.

39. Miles, J. M., R. Glasscock, J. Aikens, J. E. Gerich, and M. W. Haymond. 1983. A microfluorimetric method for the determination of free fatty acids in plasma. J. Lipid Res. 34:96-99.

40. Miles, J. M., S. L. Nissen, R. A. Rizza, J. E. Gerich, and M. W. Haymond 1983. Failure of infused $\beta$-hydroxybutyrate to decrease proteolysis in man. Diabetes. 32:197-205.

41. Hjendahl, P., M. Daleskog, and T. Kahan. 1979. Determination of plasma catecholamines by high performance liquid chromatography with electrochemical detection: comparison with a radioenzimatic method. Life Sci. 25:131-138.

42. Horber, F. F., J. Kahl, L. Lecavalier, B. Krom, and M. W. Haymond. 1989. Determination of leucine and $\alpha$-ketoisocaproic acid concentrations and specific activity in plasma and leucine specific activities in proteins using highperformance liquid chromatography. J. Chromatogr. 495:81-94.

43. Nissen, S., and M. W. Haymond. 1986. Changes in leucine kinetics during meal absorption: effect of dietary leucine availability. Am. J. Physiol. 250:E695E701.

44. Korner, A., and J. R. Debro. 1957. Solubility of albumin after precipitation by trichloroacetic acid: a simplified procedure for separation of albumin. Nature (Lond.) 178:1067.

45. Downey, R. S., A. Mellone, and D. E. Matthews. 1986. Effect of tracer infusion site on measurement of bicarbonate-carbon dioxide metabolism in dogs. J. Appl. Physiol. 60:1248-1253.

46. Glaumann, H., and J. L. E. Ericsson. 1970. Evidence for the participation of the Golgi apparatus in the intravascular transport of nascent albumin in the liver cell. J. Cell Biol. 47:555-567.

47. Peters, T., Jr., B. Fleischer, and S. Fleischer. 1971. The biosynthesis of rat serum albumin. IV. Apparent passage of albumin through the Golgi apparatus during secretion. J. Biol. Chem. 246:240-244.

48. Horber, F. F., C. M. Horber-Feyder, S. Krayer, W. F. Schwenk, and M. W. Haymond. 1989. Plasma reciprocal pool specific activity predicts that of intracellular free leucine for protein synthesis. Am. J. Physiol. 257:E385-E399.

49. Peters, T., Jr. 1975. Serum albumin. In The Plasma Proteins. F. W. Putnam, editor. Academic Press, Inc., New York. 161-163.

50. Berson, S. A., R. S. Yalow, S. Schreiber, and J. Post. 1953. Tracer experiments with $\mathrm{I}^{131}$ labeled human serum albumin: distribution and degradation studies. J. Clin. Invest. 32:746-768.

51. Hermens, W. T., G. M. Willems, and M. P. Visser. 1982. Turnover and distribution of plasma proteins. In Quantification of Circulating Proteins. W. T. Hermens, G. M. Willems, and M. P. Visser, editors. Martinus Nijhoff Publishers, The Hague, Netherlands. 43-61.

52. Snedecor, G. W., and W. G. Cochran. 1980. Statistical Methods. Iowa State University Press, Ames, IA. 141-143.

53. Snedecor, G. W., and W. G. Cochran. 1980. Statistical Methods. Iowa State University Press, Ames, IA. 149-193, 393-413.

54. Freund, R. J., and R. C. Littel. 1981. SAS for Linear Models. SAS Institute, Inc., Cary, NC.

55. Chiasson, J. L., J. E. Liljenquist, F. E. Finger, and W. W. Lacy. 1976. Differential sensitivity of glycogenolisis and gluconeogenesis to insulin infusions in dogs. Diabetes. 25:283-291.

56. Wahren, J., S. Efendic, R. Luft, L. Hagenfeldt, O. Björkman, and P. Felig 1977. Influence of somatostatin on splanchnic glucose metabolism in postabsorptive and 60-hour fasted humans. J. Clin. Invest. 59:299-307.
57. Roberts, C. M., and J. R. Sokatch. 1978. Branched chain amino acids as activators of branched chain ketoacid dehydrogenase. Biochem. Biophys. Res. Commun. 82:828-833.

58. Schwenk, W. F., and M. W. Haymond. 1987. Effects of leucine, isoleucine, or threonine infusion on leucine metabolism in humans. Am. J. Physiol. 253:E428-E434.

59. Atchley, D. W., R. F. Loeb, D. W. Richards, E. M. Benedict, and M. E. Driscoll. 1933. On diabetic acidosis: a detailed study of electrolyte balances following the withdrawal and reestablishment of insulin therapy. J. Clin. Invest. 12:297-326.

60. Beaufrere, B., F. F. Horber, W. F. Schwenk, H. M. Marsh, D. Matthews, J. E. Gerich, and M. W. Haymond. 1989. Glucocorticoids increase leucine oxidation and impair leucine balance in humans. Am. J. Physiol. 257:E712-E721.

61. Allsop, J. R., R. R. Wolfe, and J. F. Burke. 1978. Tracer priming the bicarbonate pool. J. Appl. Physiol. 45:137-139.

62. Hoerr, R. A., Y. M. Yu, D. A. Wagner, J. F. Burke, and V. R. Young. 1989. Recovery of ${ }^{13} \mathrm{C}$ in breath from $\mathrm{NaH}^{13} \mathrm{CO}_{3}$ infused by gut and vein: effect of feeding. Am. J. Physiol. 45:137-139.

63. Millikan, W. J., J. M. Henderson, J. R. Galloway, W. D. Warren, D. E. Matthews, A. McGee, and M. H. Kunter. 1985. In vivo measurement of leucine metabolism with stable isotopes in normal subjects and in these with cirrhosis fed conventional and branched-chain amino acid-enriched diets. Surgery (St. Louis). 98:405-412.

64. Heinrich, P. C., J. V. Castell, and T. Andus. 1990. Interleukin-6 and the acute phase response. Biochem. J. 265:621-636.

65. Carraro, F., W. H. Hartl, C. A. Stuart, D. K. Layman, F. Jahoor, and R. R. Wolfe. 1990. Whole body and plasma protein synthesis in exercise and recovery in humans. Am. J. Physiol. 258:E821-E831.

66. Amris, A., and C. J. Amris. 1964. Turnover and distribution of ${ }^{131}$ I-iodine labeled human fibrinogen. Thromb. Diath. Haemorrh. 11:404-422.

67. McFarlane, A. S., D. Todd, and S. Cromwell. 1964. Fibrinogen catabolism in humans. Clin. Sci. 26:415-420.

68. Takeda, Y. 1966. Studies of the metabolism and distribution of fibrinogen in healthy men. J. Clin. Invest. 45:103-111.

69. Schomerus, H., and G. Mayer. 1975. Synthesis rates of albumin and fibrinogen in patients with losing enteropathy and in a patient recovering from protein malnutrition. Digestion. 201:208-219.

70. Simmons, P. S., J. M. Miles, J. E. Gerich, and M. W. Haymond. 1984. Increased proteolysis: an effect of increases in plasma cortisol within the pharmacologic range. J. Clin. Invest. 73:412-420.

71. Darmaun, D., D. E. Matthews, and D. M. Bier. 1988. Physiological hypercortisolemia increases proteolysis, glutamine and alanine production. $\mathrm{Am}$. J. Physiol. 255:E366-E373.

72. Nair, K. S., D. Halliday, D. E. Matthews, and S. L. Welle. 1987. Hyperglucagonemia during insulin deficiency accelerates protein catabolism. Am. J. Physiol. 253:E208-E213.

73. Couet, C., N. K. Fukagawa, D. E. Matthews, D. M. Bier, and V. R. Young. 1990. Plasma amino acid kinetics during acute states of glucagon deficiency and excess in healthy adults. Am. J. Physiol. 258:E78-E85.

74. Tessari, P., S. L. Nissen, J. M. Miles, and M. W. Haymond. 1986. Inverse relationship of leucine flux and oxidation to free fatty acid availability in vivo. $J$. Clin. Invest. 77:575-581.

75. Nair, K. S., S. L. Welle, D. Halliday, and R. G. Campbell. 1988. Effect of $\beta$-hydroxybutyrate on whole-body leucine kinetics and fractional mixed skeletal muscle protein synthesis in humans. J. Clin. Invest. 82:198-205.

76. Barrieux, A., W. E. Neely, and W. H. Dillmann. 1985. Diabetes-induced alterations in the translational activity of specific messenger ribonucleic acids isolated from rat hearts. Circ. Res. 57:296-303. 